\title{
Deep properties of surface pronouns: Pronominal predicate anaphors in Norwegian and German
}

\author{
Kristine Bentzen $^{\mathrm{UT}}$, Jason Merchant ${ }^{\mathrm{UC}}$, and Peter Svenonius ${ }^{\mathrm{UT}}$ \\ ${ }^{U T}$ CASTL, University of Troms $\phi /{ }^{U C}$ University of Chicago
}

\begin{abstract}
We examine VP-anaphoric uses of Norwegian gjore det 'do it' and argue that 'surface' and 'deep' anaphoric uses of gjøre det can be distinguished. We suggest that this ambiguity is connected to the special use of det as a verbal anaphor; this special use of det, which we mark $\operatorname{det}_{\mathrm{s}}$, is distinct from the usual pronoun $\operatorname{det}\left(\operatorname{det}_{\mathrm{d}}\right)$ in that it fails to undergo Object Shift. Using this as a diagnostic, we show that the deep anaphoric gjore det really behaves like any lexical verb plus a pronominal direct object (i.e., gjøre det $_{\mathrm{d}}$, 'do it'). In the case of the surface anaphoric gjøre det, it is more as if gjøre is a light verb (it shows no aktionsart restrictions) and $\operatorname{det}_{\mathrm{s}}$ is a predicate anaphor of a special kind: it selects for an elided verbal projection. Its anaphoric properties are thus indirect, as a result of the more general requirement that elided material have a certain kind of antecedent.
\end{abstract}

Keywords: Norwegian, German, Germanic, ellipsis, predicate anaphora, pro-predicates, predicate ellipsis, comparatives

\section{Introduction}

Predicates in the Germanic languages display several possibilities for anaphora. Two of the best known involve ellipsis of the verb phrase (VPE), as in English (1a), and a use of the verb do with a singular neuter pronoun object, as in (1b).

English:

a. Jack can solve the problem; Jill can't.

b. Jack can solve the problem; Jill can't do it.

Norwegian and German both have constructions that are parallel to the English do it, as in the following (b) examples, but they also possess an alternative that is not attested in English, namely the use of a neuter pronoun with an auxiliary directly, as in the (a) examples:

(2) Norwegian:

a. Jan kan løse problemet; Kari kan ikke det. Jan can solve problem.the Kari can not it 
'Jan can solve the problem; Kari can't.'

b. Jan kan løse problemet; Kari kan ikke gjøre det.

Jan can solve problem.the Kari can not do it

'Jan can solve the problem; Kari can't do it.'

(3)

German:

a. Jan kann die Aufgabe lösen; Werner kann es nicht.

Jan can the problem solve Werner can it not

'Jan can solve the problem; Werner can't.'

b. Jan kann die Aufgabe lösen; Werner kann es nicht tun.

Jan can the problem solve Werner can it not do

'Jan can solve the problem; Werner can't do it.'

Such constructions and related anaphoric devices have been the subject of a number of previous studies. Lødrup $(1994,2012)$ and Borthen (2003) discuss the use of the pronoun det 'it' as a VP and as a DP anaphor in Norwegian. Houser et al. (2007, 2011) and Ørsnes (2011) discuss gфre det 'do it' as a VP anaphor in Danish, and Platzack (2012) addresses this construction in Swedish. Furthermore, for Norwegian, Swedish, and Danish, respectively, Anderssen and Bentzen (2012), Bentzen et al. (2013), Andréasson (2009, 2010, 2013), and Ørsnes (2013) all discuss such constructions with respect to whether the pronoun det 'it' with a VP or clausal antecedent undergoes Object Shift or not. The German facts have been investigated in López and Winkler (2000) and Ström Herold (2009) (and van Craenenbroeck 2010 examines related Dutch facts). In this paper, we aim first to give a fuller picture of the properties of these elements in Norwegian in particular, showing that there are two distinct constructions involving det 'it,' one which patterns with 'surface' anaphora and one which patterns with 'deep' anaphora. We then show that the German congener with es shows a similar mixed behavior, but differs in its behavior inside clausal comparatives, a difference we trace to a difference in the lexical specification of the pronominal element.

\section{The mixed properties of Norwegian (gjøre) det}

\subsection{VP ellipsis and anaphora in Norwegian}

Verbal predicate ellipsis and anaphora in Norwegian show both parallels to and contrasts with English constructions. The best known construction of verb phrase anaphora in English is VP ellipsis, or VPE, as already illustrated in (1a) above, and further in (4) below. Norwegian has a similar phenomenon, but its range is more restricted than that of English VPE. English VPE is allowed with any auxiliary and the copula (whether or not the copula is raised, as illustrated in (4d)):
a. Jill can solve the problem, but Jack can't.
b. Jack hasn't written a thesis, but Jill has.
c. Jill was arrested, but Jack wasn't.
d. Jill is exuberant and Jack $\{$ is/has been $\}$ too.

Norwegian allows VPE consistently only with modals, not with aspectual 'have', passive 'become', or the copula (where, if there is no verbal aspect necessary in the anaphora site, gjøre does 
not surface, though det is typically required): ${ }^{1}$

Jan kan løse problemet, men Kari kan ikke.

Jan can solve problem.the but Kari can not

'Jan can solve the problem, but Kari can't.'
a. Kari har skrevet ei avhandling, men Jan har ikke \%(gjort det).
Kari has written a dissertation but Jan has not done it
'Kari has written a dissertation, but Jan hasn't.'
Kari became arrested but Jan became not it
'Kari was arrested, but Jan wasn't.'
b. Kari ble arrestert, men Jan ble ikke\%(det).
c. Kari er begeistret og Jan $\{$ er også/har også vært $\} *($ det $)$.
Kari is enthusiastic and Jan is also/has also been it
'Kari is enthusiastic and Jan $\{$ is/has been $\}$ too.'

Thus, modals contrast with nonmodal auxiliaries and the copula. ${ }^{2}$ The general tendency is that where English has VPE, Norwegian requires or tends to have the pro-form det, together with a (tensed) modal, auxiliary, or the pro-verb gjøre. Thus Norwegian gjøre det appears to behave like an overt version of English VP-ellipsis, what Hankamer and Sag (1976) call a 'surface' anaphor (cf. Lødrup 2012; cf. also Houser et al. 2007 for a similar claim for Danish pronoun det), and what Sag and Hankamer (1984) call simply 'ellipsis'.

In initial respects, Norwegian gjøre det seems to occur in the same environments and with the same restrictions that English VPE does. Like English VPE, shown in (7), gjore det can take a range of eventuality types as its antecedent, including statives. Dynamic verbs were illustrated in various previous examples (e.g. (2b) and (6a)); stative verbs are illustrated by the data in (8).

\footnotetext{
allowed with all auxiliaries and the copula:

(i) a. Norge har kvalifisert seg til Grand Prix.

Norway has qualified REFL to Eurovision Song Contest

'Norway has qualified for the Eurovision Song Contest.'

Har Nederland (gjort det)?

has the Netherlands done it

'Have the Netherlands?'

b. Bulgaria ble stemt ut. Ble Sverige (det)?

Bulgaria became voted out became Sweden it

'Bulgaria was voted out. Was Sweden?'

c. Storbritannia er alltid med. Er Italia (det)?

Great Britain is always with is Italy it

'Great Britain is always in. Is Italy?'
}

${ }^{1}$ In a poll of Norwegian speakers, we found considerable variability on this particular point. In particular, (6a) was accepted by five of ten speakers with VPE (i.e., lacking gjøre det), and six accepted (6b) with VPE (though none accepted (6c) without det). We focus on the pattern represented by the alphabetically first author of this paper, who, like three of the speakers in the survey, accept (6a) only with gjøre det and (6b) only with det, i.e., they use VPE only in more restricted contexts, such as with modals. We leave the nature of the variability to future research.

${ }^{2} \mathrm{~A}$ systematic exception to this general pattern is found in polarity questions (see Lødrup 2012), where VPE is

These data show that there is an interaction between ellipsis type and position, apparently, of the licensing verbal elements. We will not, however, attempt to account for this interaction, which seems to be amenable to a feature co-occurrence rule account. 
a. Jack loves Kim. Does Jill?

b. Jack might not know Kim but Jill does.

a. Kari elsker Jan. Gjør Jorunn det?

Kari loves Jan does Jorunn it

'Kari loves Jan. Does Jorunn?'

b. Jeg vet ikke om Kari kjenner Joakim, men Jens må gjøre det.

I knownot if Kari knows Joakim but Jens must do it

'I don't know if Kari knows Joakim, but Jens must.'

The fact that Norwegian gjøre det can take as its antecedent stative verbal predicates headed by verbs like elske 'love' and kjenne 'know' is crucial: this fact distinguishes gjore det from what might have been thought to be its closest English congener, the verbal anaphors do it or do so. ${ }^{3}$ These anaphors, as is well known, involve the main verb $d o\left(d o_{\mathrm{MV}}\right)$, and typically are thought to require a nonstative antecedent: ${ }^{4}$

a. *Jack loves Kim. Does Jill do it/so?

b. *Jack might not know Kim, but Jill does it/so.

So in this important respect, Norwegian gjøre det behaves like VPE, not like do it.

\section{2 'Surface' anaphoric properties}

Hankamer and Sag (1976) famously proposed a distinction between what they dubbed 'surface' anaphors like VPE and 'deep' anaphors like do it, based on the variable behavior of these constructions with respect to a number of diagnostics. ${ }^{5}$ Two phenomena occur only with surface anaphors: Missing Antecedent Anaphora and the possibility of inverse quantifier scope.

\footnotetext{
${ }^{3}$ For reasons of space, we will not investigate the properties of do that, which is typically grouped with do it in particular. As Jonathan Bobaljik (p.c.) points out, do that, while infelicitous with stative antecedents, seems to license missing antecedent anaphora and perhaps to allow for inverse scope, making it an unusual mix, as we will see below. There is very little systematic investigation of the differences between these English anaphors (though see Miller and Pullum (2013) for some relevant observations). Generally the fact that do that (as opposed to do it) displays properties associated with surface anaphors fits well with our analysis, given (i) the observation by Bentzen and Anderssen (2012) that in certain respects, Norwegian shifted det is parallel to English it, while Norwegian nonshifted det has a distribution more like English that, and (ii), the fact that lack of Object Shift is also more generally correlated with surface anaphoric properties.

${ }^{4}$ The copula be (Norwegian vare) behaves differently from stative verbs in both languages. Like English VPE with the auxiliary do, Norwegian gjøre det does not permit its antecedent VP to be headed by a form of the copula vare 'be' (in such cases, vare itself must be used again).

(i) Jill is ready but John $\{$ isn't/*doesn't $\}$.

b. Jan er klar, men Kari \{er/*gjør\} ikke det.

Jan is ready but Kari is/does not it

'Jan is ready but Kari isn't.'

This property holds of English do it/so substitution as well: *Jill is ready but John doesn't do it/so.

${ }^{5}$ Hankamer and Sag (1976) related this behavior to whether the antecedent is a 'surface' form or a 'deep' form; Sag and Hankamer (1984) refine this analysis and description to replace 'surface' with 'ellipsis' tout simple, and 'deep' with 'model-interpretive.' The contrasts of interest, however, remain the same.
} 
In Missing Antecedent Anaphora (MAA), first examined in Grinder and Postal (1971), an anaphoric pronoun such as it in (10a) takes as its antecedent a noun phrase that is understood to be internal to a predicate anaphor (that is, the putative noun phrase antecedent to the pronoun is 'missing' from the overt linguistic context). VPE is the kind of predicate anaphor that can introduce such an antecedent, while do it is not. (The examples in (10) are from Bresnan 1971:591).

(10) a. My uncle didn't buy anything for Christmas, but my aunt did, and it was bright red.

b. *My uncle didn't buy anything for Christmas, so my aunt did it for him, and it was bright red.

Just like VPE in English, Norwegian gjøre det licenses Missing Antecedent Anaphora:

(11) Guro skriver aldri med penn. Jens gjør alltid det. Den er grønn.

Guro writes never with pen ${ }_{M}$ Jens does always $i t_{N} i_{M}$ is green

'Guro never writes with a pen. Jens always does. It's green.'

VPE and do it also differ in whether they permit inverse quantifier scope readings. In English, quantificational objects inside VPs typically can scopally interact with-including taking wide scope over-quantificational elements outside the VP (for example, quantificational subjects, negation, adverbs, and modals). This possibility gives rise to scopal ambiguities (see Sag 1976 and Fox 2000 for discussion). As Hankamer and Sag (1976) point out, VPE preserves scopal ambiguities that may be present in the antecedent clause, while do it does not. For example, with a universal object and an existential subject, VPE allows either scopal interpretation, while do it allows only the subject to take wide scope:

a. $\quad$ A doctor examined every patient, and then a nurse did. $(\exists>\forall, \forall>\exists)$

b. A doctor examined every patient, and then a nurse did it. $(\exists>\forall, * \forall>\exists)$

Again, Norwegian gjøre det patterns with English VPE, preserving the scopal ambiguity.

En av studentene i gruppe A svarte feil på hvert spørsmål, og en av one of students.the in group A answered wrong on every question and one of studentene i gruppe B gjorde også det. (scopally ambiguous) students.the in group $B$ did also it 'A student in group A answered every question wrong, and a student in group B did too.'6

According to these diagnostics, then, gjфre det appears to be an instance of surface anaphora.

It is worth noting here that it has sometimes been questioned whether Missing Antecedent Anaphora and inverse scope are reliable diagnostics for surface anaphora (see Merchant (2013) for this point and references therein). We believe that a pragmatic account seems unlikely to fare well for Missing Antecedent Anaphora since the pragmatically similar gjøre det samme 'do the same' (cf. Hardt et al. 2011 for English) behaves differently from gjøre det:

\footnotetext{
${ }^{6}$ It is easier to get the inverse scope reading with a nonpartitive indefinite subject in English, hence we have used one in the translation. Norwegian, on the other hand, resists weak indefinites in the high subject position, and it seems much easier to get a narrow scope reading with a partitive than with a simple indefinite. We think that the bias for a wide-scope reading of the partitive is present in both languages, and can be overridden in both languages, but the possibility of a weak indefinite in subject position in English makes that alternative salient and the narrow scope reading of the partitive commensurately more difficult.
} 
(14) Guro skriver med en grønn penn. Jens gjør det samme. \#Han kjøpte den i Oslo. Guro writes with a green pen Jens does the same he bought it in Oslo 'Guro writes with a green pen. Jens does the same thing. \#He bought it in Oslo.'

Similarly, gjфre det samme forces a wide scope reading for the indefinite subject en av studentene 'one of the students' in the second clause:

En av studentene i gruppe A svarte feil på hvert spørsmål, og en av one of students.the in group A answered wrong on every question and one of studentene i gruppe B gjorde det samme. $(\exists>\forall, * \forall>\exists)$

students.the in group $B$ did the same

'A student in group A answered every question wrong, and a student in group B did the same thing.'

The fact that 'surface' properties help determine the outcomes with these two diagnostics therefore thus suggests that both anaphora resolution and the resolution of potential scopal ambiguities in ellipsis can be sensitive not just to the meaning of larger antecedents, but to those antecedents' forms. Fox (2000) presents a detailed theory of such sensitivity for scope, and see Johnson (2012) for a proposal for anaphora.

\section{3 'Deep' anaphoric properties}

To this point, we have seen substantial parallels between Norwegian gjфre det and the English 'surface' anaphor VPE (see especially Houser et al. 2007 for similar discussion of the Danish version of gj申re det). However, there are also two ways in which gjøre det patterns with the 'deep' anaphor do it. First, like do it, gjøre det seems to be quite felicitous in discourse-initial contexts. That is, it allows for 'pragmatic control' or exophoric uses, and does not seem to require a linguistic antecedent, unlike what is traditionally reported for English VPE (but see Merchant 2004 and Miller and Pullum 2013 for important qualifications to this traditional claim):

(16) Context: Watching a pantomimed threat to break something:

a. He won't do it. / He might do it.

b. ??He won't. / ??He might.

Similarly, gjøre det needs no linguistic antecedent:

(17) Context: Watching a pantomimed threat to break something:

Han gjør det ikke. / Han kan komme til å gjøre det.

he does it not / he can come to INF do it

'He won't do it.' / 'He might do it.'

Second, $\overline{\mathrm{A}}$-extraction out of a VP ellipsis site is possible, as illustrated in (18a), but not with do it, (18b):

(18) a. How many reports did he refuse to write, and how many reports did he agree to?

b. *How many reports did he refuse to write, and how many reports did he agree to do it? 
In this respect again, gjøre det patterns with do it in that $\overline{\mathrm{A}}$-extraction is impossible, as in (19b):

a. Hvilke kaker vil du bake, og hvilke kaker vil du ikke?

which cakes will you bake and which cakes will you not

'Which cakes do you want to bake, and which cakes don't you?'

b. *Hvilke kaker vil du bake, og hvilke kaker vil du ikke gjøre det? which cakes will you bake and which cakes will you not do it

The deviance of $(19 \mathrm{~b})$ is not due to any inability of gjøre det to co-occur with the modal vil:

Jeg vil bake flere kaker, men han vil ikke (gjøre det).

I will bake several cakes but he will not (do it)

'I want to bake several cakes, but he doesn't (want to).'

We are, therefore, left with a mixed set of properties: Norwegian gjфre det patterns with 'surface' anaphors like English VPE in licensing Missing Antecedent Anaphora and inverse quantifier scope, but with 'deep' anaphors like do it in permitting 'pragmatic control' and in disallowing extraction.

\section{An ambiguity analysis}

To account for this otherwise seemingly irreconcilable admixture of behaviors, we propose a classical ambiguity analysis: there are two instances of gjøre det: one that involves a form that co-occurs with ellipsis, $\operatorname{det}_{\mathrm{s}}$, and one that involves a different pronoun that does not conceal or co-occur with ellipsis, det $_{\mathrm{d}}$. ' $\mathrm{S}$ ' is a mnemonic here for 'surface anaphor,' but also for 'sentence,' since it is connected to CP anaphora, and ' $\mathrm{D}$ ' is a mnemonic for 'deep anaphor,' but also for 'DP,' as we think that $\operatorname{det}_{\mathrm{d}}$ is an ordinary pronoun. In the analysis of pronominal structure proposed by Déchaine and Wiltschko (2002), $\operatorname{det}_{\mathrm{d}}$ would be a $\phi \mathrm{P}$, while $\operatorname{det}_{\mathrm{s}}$ would be an NP, as it can replace a predicate.

By hypothesis, then, $\operatorname{det}_{\mathrm{d}}$ is a 'deep' anaphor (like any pronoun): its resolution is achieved by linking it to a model-theoretic object, and it does not involve predicate ellipsis. ${ }^{7}$ It therefore creates no expectation that a linguistic antecedent is needed; it contains no complex internal syntactic structure of the kind that facilitates further anaphora; it does not contain quantificational elements that could undergo covert scope-shifting operations; and it does not provide appropriate origin sites for moved elements. It has the distribution of a DP, and the verb introducing it, gjøre, is a 'main' verb and must have a dynamic discourse antecedent.

$\operatorname{Det}_{\mathrm{s}}$ on the other hand, is a 'surface' anaphor: it involves (co-occurs with) ellipsis. Therefore, it co-occurs with complex unpronounced syntactic structure and thus licenses Missing Antecedent Anaphora and inverse scope. Like other ellipses, it resists exophoric control, and allows for stative antecedents. The verb which appears with it is morphologically the same as main verb gjøre 'do' but has light verb characteristics. Unlike VPE, ellipsis with det $_{\mathrm{s}}$ does not allow extraction from its complement: we return below to the issue of how to account for this anomalous behavior.

In this we draw on Helge Lødrup's (2012) analysis of certain uses of det as 'surface' anaphors.

\footnotetext{
${ }^{7}$ On a theory of pronouns that allows, or even requires, pronouns to have an elliptical component (see Elbourne 2010), of course this pronoun would too, in which case the difference would rather lie in what category of material is elided.
} 
He discusses det as a sort of 'kind' anaphor in the complement to verbs like kjøpe 'buy.' As he notes, the kind anaphor does not match in gender with its antecedent, but licenses a pronoun which does, as in MAA, as he illustrates with the example in (21). The noun hund is grammatically masculine, and thus would ordinarily correspond to the masculine/feminine ('common gender') pronoun den, but in the second conjunct of the first sentence we see the neuter pronoun det.

(21) Marit kjøpte ikke hund, men det kjøpte John. Den er veldig stor.

Marit bought not dog but it $t_{N}$ bought John $i_{M}$ is very big

'Marit didn't buy a dog, but John did. It is very big.'

This use of det is restricted to certain kinds of verbs, as Lødrup shows. Our analysis extends to all verbs, when they are replaced by gjøre.

In the following sections, we give independent evidence for this lexical ambiguity, from a differential empirical behavior under Object Shift conditions. We show that $\operatorname{det}_{d}$ and $\operatorname{det}_{s}$ are distinguished by Object Shift: $\operatorname{det}_{d}$, as a regular pronoun, undergoes Object Shift, but $\operatorname{det}_{s}$, as special head triggering predicate ellipsis, does not.

\section{1 'Deep' $\operatorname{det}_{\mathrm{d}}$ : Pragmatic control correlates with Object Shift}

There is a positive correlation between the use of deep anaphoric $\operatorname{det}_{\mathrm{d}}$ and Object Shift. Object Shift in Mainland Scandinavian is an operation that typically applies to unstressed pronominal objects, moving them across negation and adverbs, as seen by comparing the relative order of the object and the negative adverb in the examples in (22):
a. Jeg fant ikke bilen.
I found not car.the
'I didn't find the car.'
b. Jeg fant den Masc $_{\text {ikke. }}$
I found it not
'I didn't find it.'

Holmberg (1999) argues that the triggering feature for Object Shift is [-Focus]; elements negatively specified for $[ \pm$ Foc] have to move out of the focus domain (cf. also Mikkelsen 2011 for a focus-based account of Object Shift).

The generalization is sometimes made on the basis of patterns like that in (22) that pronouns shift while full DPs do not, but det often fails to shift when it is referentially linked to a $\mathrm{CP}, v \mathrm{P}$, or kind-denoting noun phrase. Anderssen and Bentzen (2012) and Bentzen et al. (2013) specifically investigate such cases, and propose that $\operatorname{det}$ with a $\mathrm{CP}, v \mathrm{P}$, or kind-denoting antecedent do undergo Object Shift when they constitute familiar or continuing topics, but remain in situ when they constitute aboutness topics. We suggest that the reference of a shifted det is resolved in the same way as for deep anaphors, $\operatorname{det}_{\mathrm{d}}$, even when its antecedent is clausal, eventive, or kind-denoting. ${ }^{8}$ In the case of pragmatic control discussed in section 2.3, det $_{\mathrm{d}}$ does not have a structural antecedent, but rather refers to a discourse topic that has been established in a context, possibly extralinguistically. In pragmatic control contexts, the pronoun $\operatorname{det}_{\mathrm{d}}$ constitutes a [-Focus] element and by referring to

\footnotetext{
${ }^{8}$ See also Lødrup (1994, 2012), Andréasson (2009) and Ørsnes (2013) for discussions of Object Shift and pronouns referring to $\mathrm{CPs}, \nu \mathrm{Ps}$, and kind-denoting noun phrases.
} 
a discourse topic, it functions as a continuing topic. Some feature on $\operatorname{det}_{\mathrm{d}}$ causes it to obligatorily undergo Object Shift. Obligatory shift of a pragmatically controlled pronoun is illustrated in (23).

Watching John pretending to break our new expensive vase:

Slapp av, han gjør $\{$ det $\}$ ikke $\{*$ det $\}$.

relax off he does it not it

'Relax, he won't do it.'

This behavior of pronouns without linguistic antecedents, that is, pronouns with 'deep' anaphoric properties, can be observed also with verbs other than gjøre, such as prøve 'try':

(24) Watching John climbing up a tall bridge, and Jack getting ready to do the same:

Jeg prøver $\{\operatorname{det}\}$ ikke $\{* \operatorname{det}\}$.

I try it not it

'I won't try it.'

In contrast, we do not expect this kind of correlation between Object Shift and surface det $_{\mathrm{s}}$. Rather, we predict that Object Shift will be incompatible with Missing Antecedent Anaphora, inverse quantifier scope, and extraction, as discussed further below.

\subsection{Surface det $_{\mathrm{s}}$ : 'Surface' properties correlate with lack of Object Shift}

The pronoun that appears with gjore det when this anaphor has 'surface' properties, i.e. $\operatorname{det}_{\mathrm{s}}$, is different from the pronoun $\operatorname{det}_{\mathrm{d}}$ discussed in the previous section.

First, when Missing Antecedent Anaphora is licensed, Object Shift becomes impossible (normally; we discuss a counterexample momentarily). We mark the $d$ and $s$ subscripts on the two different instances of det to call attention to this aspect of the analysis, though they have the same form, and translate $\operatorname{det}_{\mathrm{d}}$ as 'it' when it is possible to preserve the meaning of the original.

a. Guro skriver aldri med penn. Jens gjør alltid det $_{\mathrm{s}}$. Den er grønn.

Guro writes never with pen ${ }_{M}$ Jens does always $i t_{N} i_{M}$ is green

'Guro never writes with a pen. Jens always does. It's green.'

b. Guro skriver aldri med penn. Jens gjør det $_{\mathrm{d}}$ alltid. \#Den er grønn.

Guro writes never with pen ${ }_{M}$ Jens does it ${ }_{N}$ always $i_{M}$ is green

'Guro never writes with a pen. Jens always does it. \#It's green.'

Second, Object Shift is incompatible with an inverse scope reading-such readings are available only when the pronoun has not shifted:

En av studentene i gruppe A svarte feil på hvert spørsmål,... one of students.the in group A answered wrong on every question

'A student in group A answered every question wrong, ...'

a. $\quad . . .0 g$ en av studentene i gruppe B gjorde også det.$(\exists>\forall, \forall>\exists)$

and one of students.the in group $B$ did also it

'...and a student in group B did too.'

b. $\quad \ldots$ og en av studentene i gruppe B gjorde det $_{\text {d }}$ også. $(\exists>\forall, * \forall>\exists)$

and one of students.the in group $B$ did it also 
'... and a student in group B did it too.'

The correlation between 'deep' properties and Object Shift and between 'surface' properties and the failure to undergo Object Shift is captured, on our analysis, by positing an ambiguity in the anaphor itself. The regular pronoun $\operatorname{det}_{\mathrm{d}}$ has the distribution of a pronoun, and thus must be introduced in an argument position, such as the object position of main verb gjøre 'do'; this verb is a dynamic verb like its English main verb counterpart. The ellipsis site marker $d e t_{\mathrm{s}}$, on the other hand, has the distribution of a predicate, and is supported by an auxiliary or by a light verb use of gjøre, which is not restricted to dynamic contexts, much as English auxiliary do is not.

The combination of these properties makes a novel prediction, since $\operatorname{det}_{\mathrm{s}}$ involves ellipsis and therefore allows stative antecedents and disprefers exophoric use, while $\operatorname{det}_{\mathrm{d}}$ allows exophoric use but is not compatible with a stative predicate. This combination predicts that if a salient or manifest property in the context is stative, neither an Object Shifted nor an in situ use of det will be found: the shifted use is ruled out, since it would require $\operatorname{det}_{\mathrm{d}}$, which cannot have a stative interpretation, and the in situ use is ruled out, since $\operatorname{det}_{\mathrm{s}}$ requires a linguistic antecedent. Exactly this is the case, as the following example shows:

[Watching John doing the dishes, which he clearly doesn't like doing:]

*Huffda, han gjør $\left\{\operatorname{det}_{\mathrm{d}}\right\}$ ikke $\left\{\operatorname{det}_{\mathrm{s}}\right\}$. (where det = 'like doing the dishes') oh.dearhe does it not it

(*'Oh dear, he doesn't (do it).')

A further fact of relevance here is that the use of the 'deep' anaphor is often dispreferred when the 'surface' one can be used: in Norwegian this can be seen in the fact that when a linguistic antecedent is available, Object Shift sometimes becomes strongly dispreferred:

Kari går ofte på kino. John gjør $\left\{\right.$ ??det $\left._{\mathrm{d}}\right\}$ ikke $\left\{\operatorname{det}_{\mathrm{s}}\right\}$.

Kari goes often on cinema John does it not it

'Kari often goes to the movies. John doesn't (??do it).'

The fact that the shifted pronoun is odd here, and that it is not the case that both variants are freely available, seems to pattern with a range of other facts known about elliptical anaphoric devices. For reasons explored in Merchant (2013) and van Craenenbroeck (2012), it appears that across a variety of constructions, the availability of a 'surface' anaphor tends to inhibit the use of an otherwise equivalent 'deep' anaphor. Roughly speaking, when ellipsis can be used, it should be; when ellipsis fails, other, contextually equivalent, anaphoric devices can be made use of. In the case of gj申re det, this preference seems especially strong in some cases, such as (28), and less so in others, such as (25b) and (26b), for reasons that are unclear at this point. However, it seems that the same pattern holds of the English $d o$ and $d o$ it here, as seen in the translations. And while we can understand why $\operatorname{det}_{d}$, as a pronoun, would have to undergo Object Shift when it can, we will postpone until section 3.4 below an account of why the prosodically otherwise similar det $_{s}$ cannot shift.

Lødrup $(1994,2012)$ observes that the kind-denoting det which occurs with verbs like kjфpe can undergo Object Shift, citing the example in (29) (bil 'car' is masculine, so the referential pronoun would have to be den, and would suggest, incongruously here, that John and we bought the same car at the same time). 
John kjøpte bil da vi kjøpte det, men han kjøpte det ikke på grunn av oss. John bought car when we bought it but he bought it not on ground of us 'John bought a car when we did, but he didn't buy it because of us.'

Both instances of $d e t$ 'it' are neuter, despite the fact that bil 'car' is masculine. The second instance of det is Object-shifted across ikke 'not.' Lødrup concludes that det $_{\mathrm{s}}$ can undergo Object Shift when it represents given information. We have controlled for this factor in the examples in this paper, so that our results are compatible with Lødrup's position. But an alternative explanation is that the Object-shifted det in (29) is actually a $\phi$ P, i.e. our $\operatorname{det}_{\mathrm{d}}$. In that case, we would have to allow $\operatorname{det}_{\mathrm{d}}$ to have a 'kind' interpretation under certain circumstances-crucially here, the antecedent has a kind interpretation, a situation which is often correlated with lack of gender (and number) agreement (see Borthen 2003). ${ }^{9}$ Thus we will set aside these cases where det is contextually old and assume that elsewhere, Object Shift is a good test for distinguishing $\operatorname{det}_{\mathrm{s}}$ from $\operatorname{det}_{\mathrm{d}}$.

\subsection{Extraction}

The ambiguity analysis accounts for why gjøre det seems to display both 'surface' and 'deep' behaviors. But positing an ambiguity raises a new question: why is $\overline{\mathrm{A}}$-extraction uniformly disallowed? As we saw above in (19b), $\overline{\mathrm{A}}$-extraction from the site of det is banned, regardless, it seems, of whether the det can be analyzed as 'surface' or 'deep.'

The answer comes from the behavior of $\overline{\mathrm{A}}$-extraction in the presence of anaphoric det more generally: there is a use of Norwegian det which systematically blocks $\overline{\mathrm{A}}$-extraction from an associated CP. First, note that in Norwegian, most finite CP complements can be accompanied by an overt pronoun $d e t$, which we believe to be identical to $\operatorname{det}_{\mathrm{s}}$ (The examples in (30)-(31) are from Bentzen 2012).
a. Han påstod at Jon hadde mistet brillene sine. he claimed that Jon had lost glasses.the his 'He claimed that Jon had lost his glasses.'
b. Han påstod det at Jon hadde mistet brillene sine. he claimed it that Jon had lost glasses.the his 'He claimed that Jon had lost his glasses.'

As discussed by Bentzen (2012), extraction from embedded clauses when these clauses are associated with det is impossible; compare the acceptable examples (31a) and (31c) without det to the unacceptable examples (31b) and (31d) : ${ }^{10}$
a. $\quad[\text { Hvem }]_{i}$ påstod han at $t_{i}$ hadde mistet brillene sine? who claimed he that had lost glasses.the his 'Who did he claim had lost his glasses?'
b. $*[\text { Hvem }]_{i}$ påstod han det at $\mathrm{t}_{i}$ hadde mistet brillene sine? who claimedhe IT that had lost glasses.the his

\footnotetext{
${ }^{9}$ Examples like (29) also allow MAA of the restricted kind discussed by Lødrup, i.e. an instance of a car-kind introduced by neuter det can also be referred back to with a masculine den; cf. (21).

${ }^{10}$ Note that only varieties of Norwegian which lack a that-trace effect allow examples like (31a), but the point is illustrated by $(31 \mathrm{c}-\mathrm{d})$ even for those varieties which observe the that-trace effect.
} 
c. $\quad[\mathrm{Hva}]_{i}$ påstod han at Jon hadde mistet $\mathrm{t}_{i}$ ?

what claimed he that Jon had lost

'What did he claim that Jon had lost?'

d. *[Hva $]_{i}$ påstod han det at Jon hadde mistet $\mathrm{t}_{i}$ ?

what claimed he IT that Jon had lost

'What did he claim that Jon had lost?'

Thus if the constraint that accounts for this pattern (see below for some more discussion) is sensitive simply to the presence of a determiner-like element associated with an extraction domain, the constraint should apply in the case of predicate-replacing det (what we are calling $\operatorname{det}_{\mathrm{s}}$ ) as well.

\subsection{Inverse quantifier scope}

Given this state of affairs, it now becomes urgent to examine the case of inverse quantifier scope. Recall that such scoping is possible with $d t_{\mathrm{s}}$, as shown in the repeated example here:

En av studentene i gruppe A svarte feil på hvert spørsmål, og en av one of students.the in group A answered wrong on every question and one of

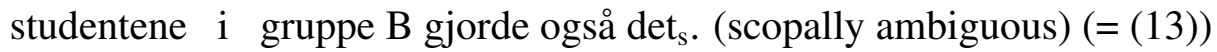
students.the in group $B$ did also it

'A student in group A answered every question wrong, and a student in group B did too.'

It is often assumed that inverse quantificational scope is derived by a covert $\overline{\mathrm{A}}$-movementQuantifier Raising_-of the object to a position c-commanding the subject, yielding structures such as the following at LF:

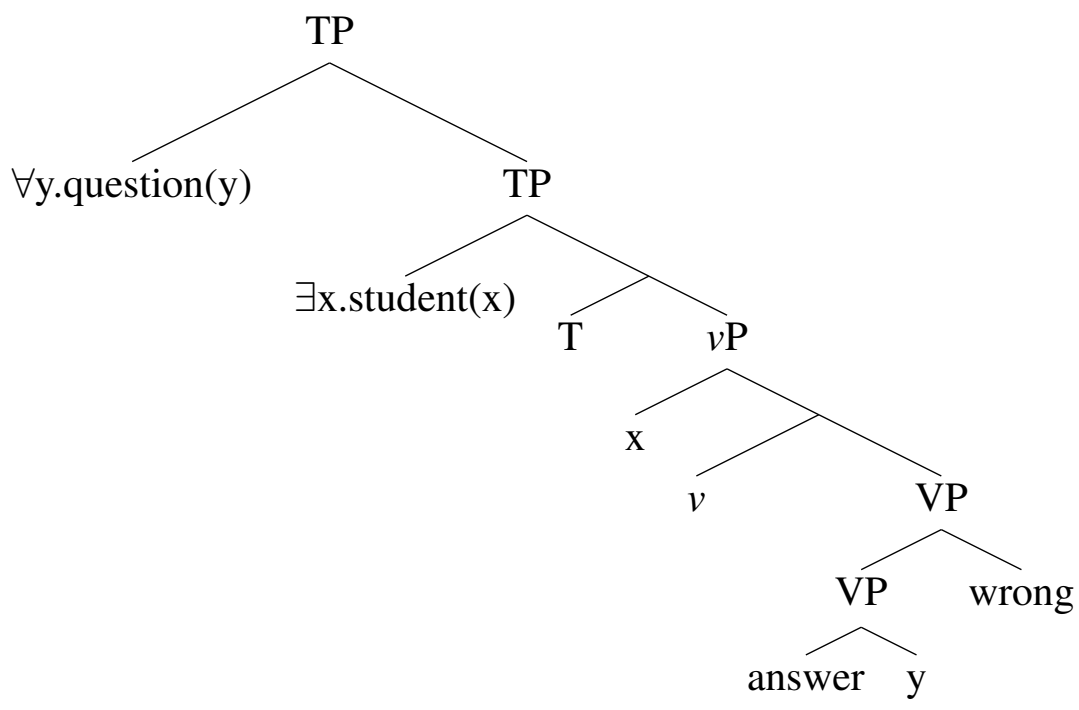

In the VP-anaphor clause, gjøre could be assumed to be at the position of $v$ in this tree, and $\operatorname{det}_{\mathrm{s}}$ could be assumed to replace the VP, as Houser et al. (2007) propose for the parallel construction in Danish.

But in that case, inverse scope would involve $\mathrm{QR}$ across $\operatorname{det}_{\mathrm{s}}$. If $\mathrm{QR}$ is a kind of $\overline{\mathrm{A}}$-movement, as standardly assumed, then it should pattern with overt $\overline{\mathrm{A}}$-movement, and inverse scoping should be 
disallowed, contrary to fact. The fact that inverse scope is possible is consistent, however, with the derivation of this scoping proposed in Johnson and Tomioka (1998). Johnson and Tomioka (1998) posit that object-over-subject inverse scope should be analyzed as involving the interpretation of the subject in a lower, predicate-internal position (either by means of lowering at LF or reconstruction, however implemented). Scope inversion is derived by QRing the object not over the overt position of the subject in specTP or higher, but to the outer edge of the extended projection of the verb, above the base or reconstructed position of the subject:

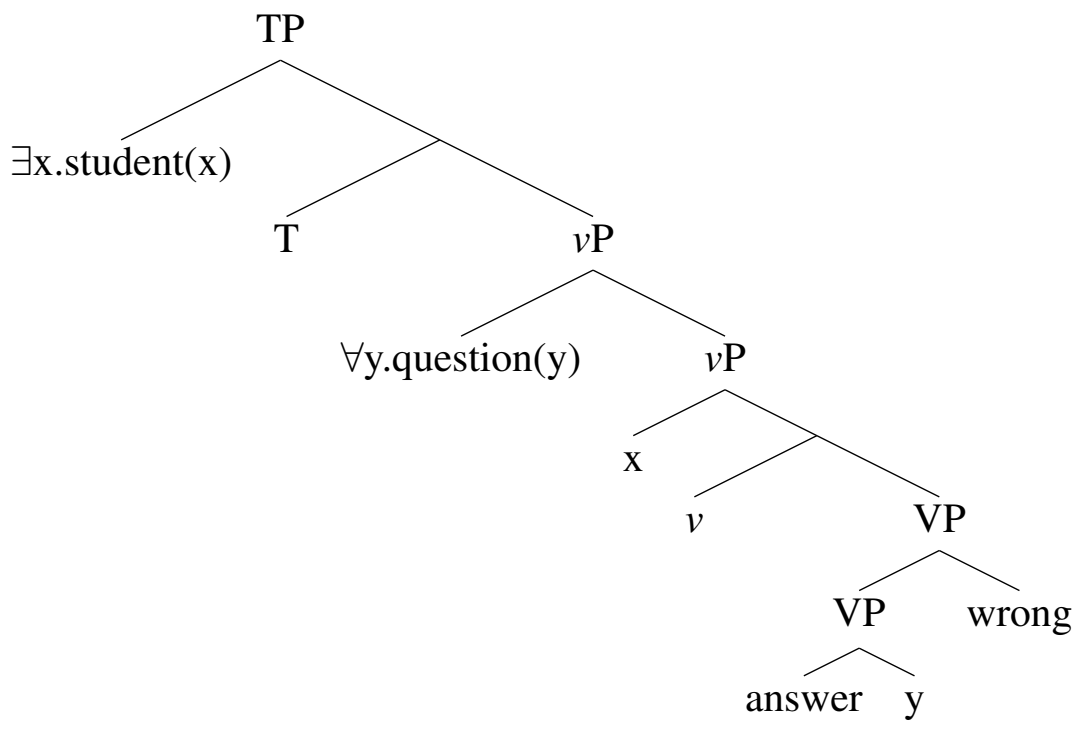

If what is unpronounced in ellipsis structures with gjøre det were the VP, then QR to the edge of $v \mathrm{P}$ would still cross $\operatorname{det}_{\mathrm{s}}$ (assuming the latter to be sister to the elided constituent, as we suggest below). Thus, in order for QR not to cross $\operatorname{det}_{\mathrm{s}}$, we must assume that the ellipsis site is the larger $v \mathrm{P}$.

This means that we must assume that ordinary A-movement of the subject out of the ellipsis site is not blocked, even though $\overline{\mathrm{A}}$-movement is. There is in fact evidence that A-movement is not blocked by gjøre det. The first such evidence comes from cases where a subject must get its thematic interpretation from the verb, for example in cases like the following.
a. En tanke slo meg.
a thought struck me
'A thought struck me.'
b. Det slo meg en tanke.
it struck me a thought
'A thought struck me.'

When slå 'strike' combines with a narrow semantic range of objects such as 'thought' or 'idea' and an animate experiencer argument, it has a meaning different from its literal physical meaning (as in English), something like '(experiencer) suddenly had a thought.' This quasi-idiomatic interpretation can arguably only come about if the theme is an internal argument of the predicate, and would not be expected to enter into nonlocal relations such as control or pronominal anaphora. In fact, the neutral word order in the impersonal variant, illustrated in (35b), suggests that the theme 
might even originate lower than the experiencer.

At least in such constructions, then, we can be sure that the subject is raising from within the verb phrase, and could not be contributed by gjøre in some kind of control construction under standard conceptions. Thus, if we can show that even with these verbs, the verb phrase can be replaced by gj申re det, then we will have shown that A-movement of the subject escapes the ellipsis site.

To see that this in fact is so, consider first (36). In this example, the VP anaphor gjøre det stands in for the verb phrase slå meg 'strike me,' while the subject det, standing for 'a thought,' raises from the anaphoric $v \mathrm{P}$, just in case we have $\operatorname{det}_{\mathrm{s}}$ (and hence no Object Shift).
a. Jeg trodde at en tanke skulle slå meg, men...
I thought that a thought should strike me but
'I thought that a thought would strike me, but ...'
b. ... det gjorde aldri $\operatorname{det}_{\mathrm{s}}$.
it did never it
'... one never did.'
c. *... det gjorde $\operatorname{det}_{\mathrm{d}}$ aldri.
it did it never
$\left({ }^{*} \cdot . .\right.$. one never did it.')

The pronominal subject in the second conjunct clause in (36b) is in the neuter form, consistent with a 'kind' interpretation. ${ }^{11}$ It can be made clearer that the subject is raising if it shows gender agreement with its antecedent, which means we have to rule out the kind-interpretation. This can be done by making the quasi-referential noun phrase en tanke 'familiar' enough to support regular, nonkind anaphora to the common-gendered antecedent en tanke, as in (37). Once again, as expected, Object Shift eliminates the idiomatic reading of the $v \mathrm{P},(37 \mathrm{c})$ :

a. Jeg satt klar med penn og papir, fordi jeg visste at en smart tanke skulle I sat ready with pen and paper because I knew that a smart thought should slå meg.

strike me

'I was sitting ready with pen and paper, because I knew that a clever thought would strike me.'

b. Så gjorde den plutselig $\operatorname{det}_{\mathrm{s}}$.

so did it suddenly it

'And then it suddenly did.'

c. \#Så gjorde den $\operatorname{det}_{\mathrm{d}}$ plutselig.

so did it it suddenly

(\#'And then it suddenly did it.')

Finally, we observe that gjøre det $_{s}$ is possible with antecedents headed by unaccusative, passive, and raising verbs. In (38a)-(38b) Object Shift is not possible, indicating that only gjøre det $_{s}$ is available here. In contrast, (38c) does allow Object Shift, but the interpretation is different with and without Object Shift of det. Without Object Shift, the antecedent of det is the complete preceding

\footnotetext{
${ }^{11}$ The form is identical with that of an expletive, opening the possibility that the subject is not raised at all in (36). But impersonal clauses cannot normally have nonimpersonal clauses as their antecedents, in VP-anaphora.
} 
clause and the interpretation is that she does not seem to understand me. With Object Shift, on the other hand, the antecedent of det is only the infinitive clause and the interpretation is that she does not understand me.

a. Vokser den på trær? Nei, den gjør ikke det. / *Nei, den gjør det ikke. grows it on trees no it doesnot it no it does it not 'Does it grow on trees? No, it doesn't.'

b. Ble han arrestert? Nei, han ble ikke det. / Nei, han ble det ikke. became he arrested no he became not it no he became it not 'Was he arrested? No, he wasn't.'

c. Han virker for å forstå meg, men hun gjør ikke det / hun gjør det ikke. he seems for to understand me but she does not it she does it not 'He seems to understand me, but she doesn't.'

We therefore propose that $d e t_{\mathrm{s}}$ cooccurs with an elided verbal predicate, taking as inspiration the similar proposal in Elbourne (2008), though our implementation differs in details. In particular, we suppose that $\operatorname{det}_{\mathrm{s}}$ is an N, following the Déchaine and Wiltschko (2002) decomposition of pronominal structure, that hosts an E-feature (the latter triggering ellipsis of its sister), and that originates as the sister of the predicate. We take the predicate in this case to be the highest argument-introducing verbal projection: on many conceptions, $v \mathrm{P}$. The gjore that occurs with this det can then be analyzed as a species of $v$ which selects for this head (and licenses the E feature, for example). ${ }^{12}$ The resulting structure is the following:

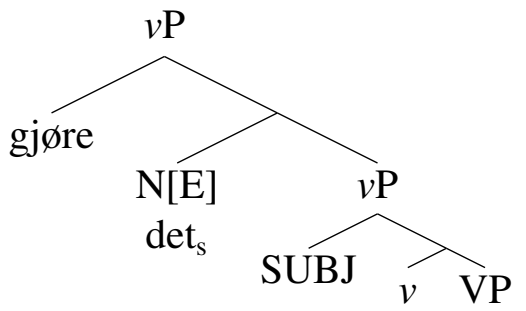

The node immediately dominating $\mathrm{N}$ here is unlabeled in (39). Given the flexibility of det $_{\mathrm{s}}$ to attach to a wide variety of predicative constituents, without affecting selectional relations, we assume that it is adjoined. Hence the unlabeled node would be a projection of the verbal material below it. ${ }^{13}$

This structure also allows us to understand why the otherwise prosodically light det $_{\mathrm{s}}$ cannot undergo Object Shift: if Object Shift targets only the category of ordinary pronouns ${ }^{14}$ (distinguished by additional features such as [-Foc] or the like), then $\operatorname{det}_{\mathrm{s}}$, as an $\mathrm{N}$, does not qualify as a potential target for Object Shift. (It may front, but this is true of a much wider range of constituents.)

An alternative possibility would be that $\operatorname{det}_{\mathrm{s}}$ realizes a head in the clausal skeleton, as proposed by Sportiche (1995) for the French predicate clitic le. This allows for extraction of a comparative operator out of the missing predicate phrase, as in (40).

\footnotetext{
${ }^{12}$ We will not pursue the exact identity of the light verbal element. It could be a raising light verb, or a low auxiliary, as in Houser et al. (2011) or Platzack (2012), or perhaps Voice in the conception of Collins (2005).

${ }^{13}$ Compare Cable's (2010) proposal for an adjoined operator $\mathrm{Q}$ in his analysis of $w h$-movement.

${ }^{14}$ In Danish, locative particles meaning 'here' and 'there' also shift.
} 
But Norwegian det $_{\mathrm{s}}$ has no clitic-like properties, and proposing a high position outside the predicate would leave it mysterious why det should block $\overline{\mathrm{A}}$-extraction (as indeed the French le does not).

Houser et al. (2007) propose a kind of overwriting analysis, where the Danish det 'replaces' a $v \mathrm{P}$; this $v \mathrm{P}$ by hypothesis is marked as [top], which, as an $\overline{\mathrm{A}}$-feature, competes with any [wh] feature internal to the $v \mathrm{P}$ being replaced. We are reluctant to posit overwriting as a mechanism, but will propose that a feature from the $\overline{\mathrm{A}}$-system is present in these structures, in order to explain the impossibility of $\bar{A}$-extraction.

We are now in a position to see the complete analysis of cases of inverse quantifier scope such as (13). In such examples, the quantificational subject reconstructs to its base position inside the $v \mathrm{P}$, while the quantificational object $\mathrm{QRs}$ to an immediately c-commanding position. This instance of $\mathrm{QR}$ does not cross det, which blocks all $\overline{\mathrm{A}}$-extraction from its complement; the resulting $\mathrm{LF}$ structure is shown schematically in (41):

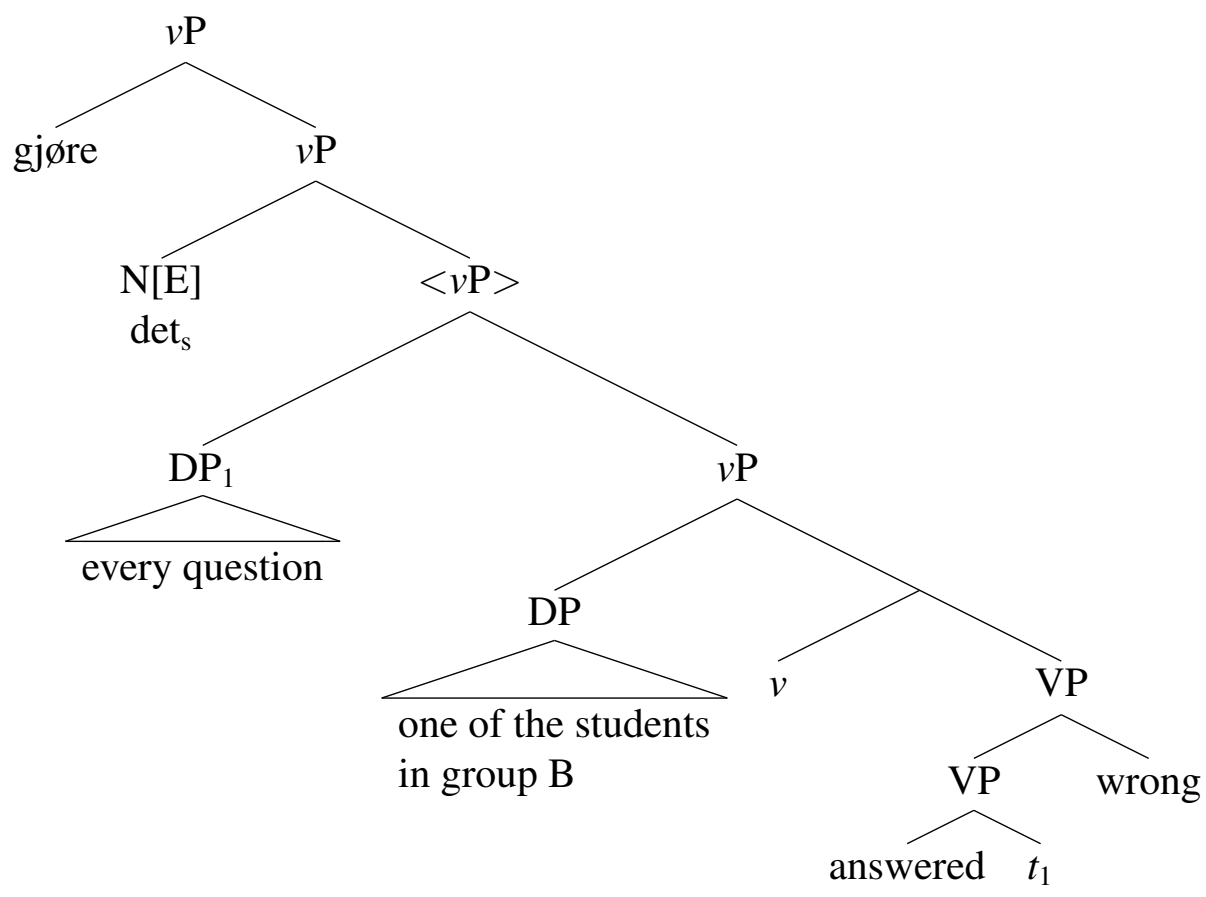

Here we represent gjøre as a light verb $v$ taking a $v \mathrm{P}$ complement; it is the presence of a $v \mathrm{P}$ below gjøre which makes this structure large enough to support inverse scope in the ellipsis site, in contrast to the structure in (34) previously discussed. In contrast, main verb gjøre, as an ordinary main verb, would not take a $v \mathrm{P}$ complement, and would hence not provide any possibility of inverse scope.

We suppose the impossibility of $\bar{A}$-extraction could be derived in one of two ways. One, it could be due to the nominalizing property that accompanies det: predicates or CPs that 'associate' 
with det appear to have more definite nominal properties than those that do not, and for reasons that are not entirely clear, $\overline{\mathrm{A}}$-extraction from such phrases is degraded. Two, det $_{\mathrm{s}}$ might have some kind of $\overline{\mathrm{A}}$-feature that would interfere with $\overline{\mathrm{A}}$-extraction (compare the similar reasoning found in Houser et al. 2007). ${ }^{15}$ In any case, it is not enough to claim that det-associates are 'islands' tout court.

Modal examples reveal an additional property of the reconstruction analysis of the observed inverse quantifier scope. In modal examples without anaphora or ellipsis, inverse scope can also be found, as illustrated in (42a), which permits both the surface and inverse scope readings. This scopal ambiguity is preserved when a modal co-occurs with det directly, as we showed in (5) above-when the antecedent clause is ambiguous, a continuation such as (42b) retains the ambiguity (and, as is expected, the ambiguity must be resolved in the same way in both clauses, making this discourse 2-ways, not 4-ways, ambiguous; see Sag 1976 and much later work):

a. Jeg kan bake hver eneste kake på lista... $(\diamond>\forall, \forall>\diamond)$

I can bake every single cake on list.the

'I can bake every cake on the list...'

b. $\quad$... og Per kan også $\operatorname{det}_{\mathrm{s}} .(\diamond>\forall, \forall>\diamond)$

and Percan too it

'... and Per can too'

However, an elided quantifier cannot take scope over a surface modal followed by gjøre det (Object Shift cannot be applied when the main verb is not finite, so there is no surface way to distinguish $\operatorname{det}_{\mathrm{d}}$ from $\operatorname{det}_{\mathrm{s}}$ here; we don't expect $\operatorname{det}_{\mathrm{d}}$ to provide scopal ambiguity, so the interesting datum here concerns $\operatorname{det}_{\mathrm{s}}$ ):

Jeg kan bake hver eneste kake på lista og Per kan også gjøre det . $_{\text {. }}$

I can bake every single cake on list.the and Per can too do it

'I can bake every cake on the list and Per can also do it.' $(\diamond>\forall, * \forall>\diamond)$

We have already seen why inverse scope of an object quantifier with respect to a modal selecting gjore is not expected: even a derivation with $\operatorname{det}_{\mathrm{s}}$ will fail to provide a possible landing site for $\mathrm{QR}$ of the object to a position c-commanding any of the possible positions of the modal (since the object cannot raise past det), nor can the modal reconstruct to a position under gjøre. Thus, (44) gives a structure with the highest possible landing site after QR of the object quantifier (with the traces of the subject suppressed):

\footnotetext{
${ }^{15}$ A third possibility would be to follow Aelbrecht (2010) in appealing to the relative timing of $\bar{A}$ - vs. A-extraction vis-à-vis ellipsis. Our data are consistent with such an implementation.
} 
(44)

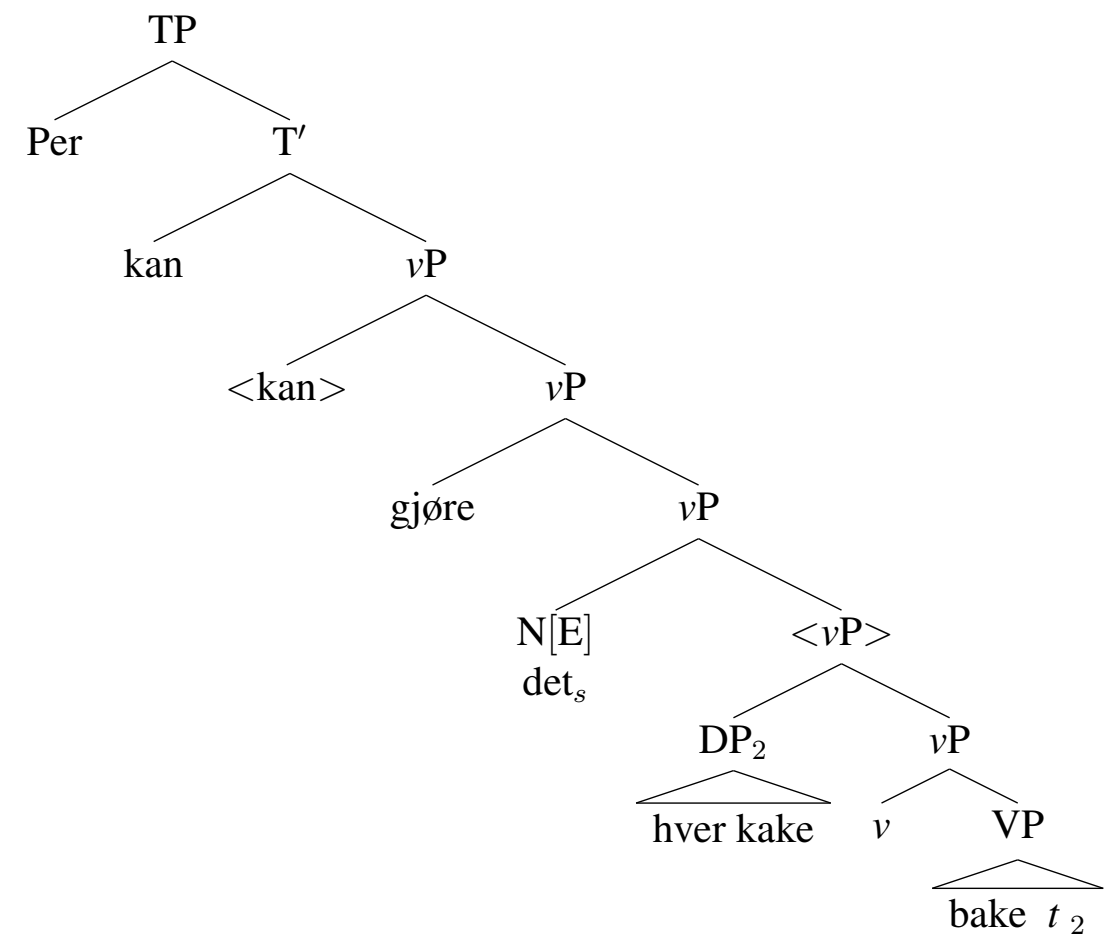

When $\operatorname{det}_{\mathrm{s}}$ occurs with a modal directly, however, without the co-presence of gjøre, additional possibilities for the position of $\mathrm{N}[\mathrm{E}]$ are available: in particular, $\mathrm{N}[\mathrm{E}]$ can attach to the $v \mathrm{P}$ originally headed by kunne (the citation form of kan 'can') itself. Taking this option means that an object quantifier can $\mathrm{QR}$ to a $v \mathrm{P}$-peripheral position which does not cross $\operatorname{det}$, but from which the quantifier can c-command the base position of the moved modal. If moved modals (like other heads) can reconstruct for purposes of scope, then an LF can be generated in which the object takes scope over the modal: 


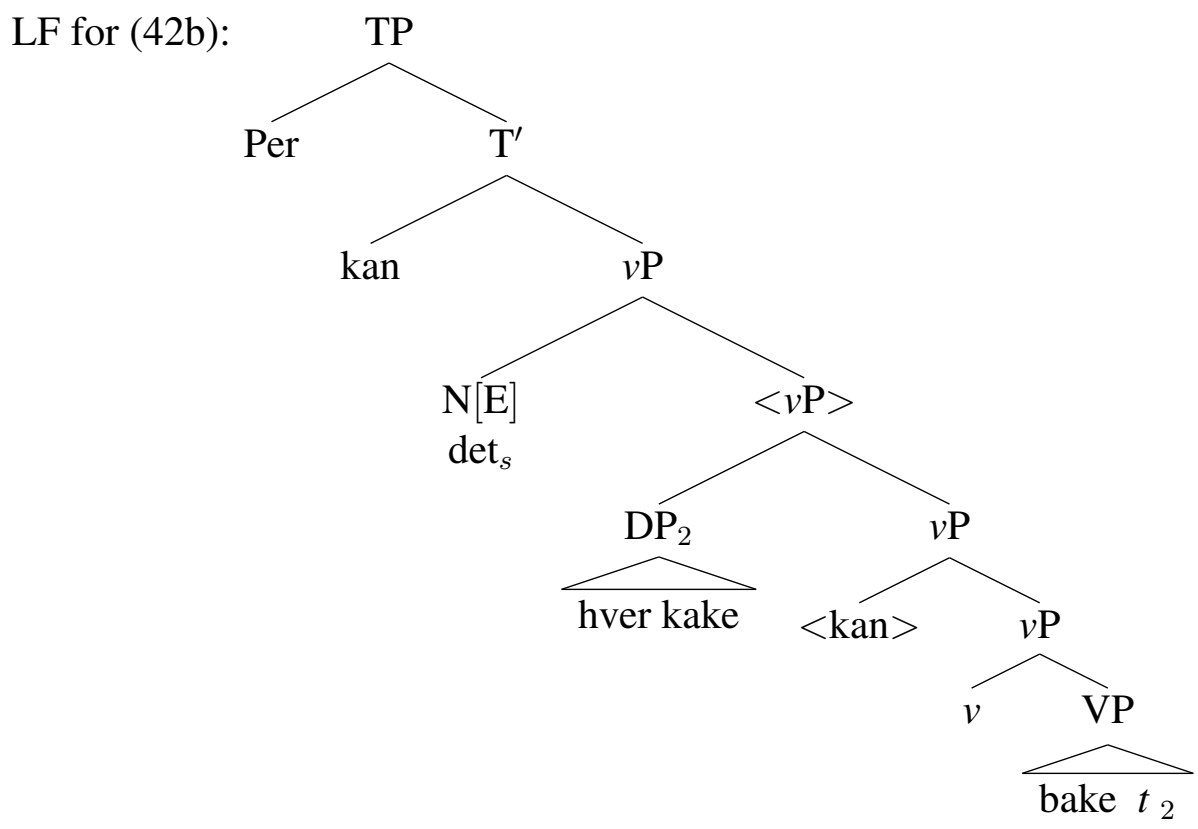

In the tree above, additional support can be seen for our contention that $\operatorname{det}_{\mathrm{s}}$ is adjoined: Under standard conceptions of head movement, it would not be possible for the modal verb kunne to move across an intervening head; but it must originate inside the ellipsis site in order to be interpreted inside the scope of the elided quantifier, and it must move out of the ellipsis site in order to be pronounced (making this an example of 'verb-preserving VP-ellipsis,' observed in languages like Irish and Russian).

Note also that Object Shift is impossible with either reading:

*Jeg kan bake hver eneste kake på lista og Per kan det ${ }_{\mathrm{d}}$ også.

I can bake every single cake on list.the and Per can it too

('I can bake every single cake on the list and Per can it too.')

This is because only $\operatorname{det}_{\mathrm{d}}$ can shift, and the modal sense of kunne does not allow a DP direct object.

\section{Predicate anaphoric it in German and comparatives}

We have explored Norwegian in some detail to this point; in this final section, we turn to a more cursory but nevertheless illuminating examination of some related facts from German. This language (like its relatives Yiddish and Dutch, among others) also permits a use of the singular neuter pronoun with certain modal verbs and with cognates of English do to render predicate anaphora. In this section, we briefly review the major claims that have been made about these elements, which are consistent with the Norwegian facts examined thus far, and then introduce a new set of facts that resist a simple and otherwise attractive assimilation to the Norwegian $\operatorname{det}_{d}$.

The German third singular neuter nondeictic pronoun es, as we saw above in (3), can stand in for a verbal predicate, as seen in the following example (from López and Winkler 2000; see also Winkler 2005, 2013): 
Ben will die Aufgabe lösen, aber ich weiss nicht, ob er es kann.

Ben wants the task solve but I know not if he it can

'Ben wants to solve the problem, but I don't know if he can.'

Pragmatic control is permitted with such examples, and typical $\overline{\mathrm{A}}$-extractions are not, as discussed in Winkler (2013), who gives the following example:

*Ich weiss, wen Sandra einladen muss, aber ich weiss nicht, wen Jan es muss.

I know who Sandra invite must but I know not whom Jan it must

('I know who Sandra must invite, but I don't know who Jan must <invite >.')

To this example we add the following, which demonstrate that German es is also not possible with the extraction of amount-denoting DPs in questions, nor in degree-denoting phrasal comparisons (using an amount relative):

a. Wir wissen, wieviele Lieder Marie singen kann, aber wir wissen nicht, wieviele we know how.manysongs Marie sing can but we know not how.many

Lieder ihr Grossvater (*es) konnte. songs her grandfather it could

b. Marie kann mehr Lieder singen, als nur die, die ihr Grossvater (*es) konnte. Marie can more songs sing than just those which her grandfather it could

These examples further show that German has some kind of VP ellipsis with modals (see especially Aelbrecht 2010 for discussion); while these examples are rarer, they do occur, though we will not pursue an investigation of their properties further here.

A reasonable conclusion to draw from such contrasts is the one that Winkler and other re-

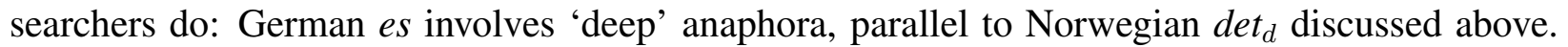
Avoiding such a conclusion would require that one posit some other reason that such $\bar{A}$-extractions are ill-formed. One possibility would be to link such ill-formedness, as in Norwegian, to the wellknown fact that extraction from it-associates in German is not possible (see Berman 1998):

Was hat er (*es) gesagt, dass er gelesen hat?

what has he it said that he read has

'What did he say that he read?'

But barring any evidence to the contrary, there seems no reason even to search for such alternative explanations. Unfortunately, there is one construction whose properties do indeed force us to refine the claim that $\overline{\mathrm{A}}$-extraction from $e s$-predicate anaphors is never found: comparatives.

\subsection{Comparatives and predicate anaphors}

In Norwegian, the interaction between comparatives and predicate anaphors is as expected: since clausal comparatives involve $\overline{\mathrm{A}}$-extraction in the than-clause (following Chomsky 1977 and many since), we do not expect to find licit occurrences of (gjøre) det inside clausal standards that involve comparison of predicate-internal elements. And indeed, in Norwegian, we do not:

a. Marie kan synge flere sanger enn bestefaren hennes kunne (*gjøre det).

Marie can sing more songs than grandfather.the her could do it 
'Marie can sing more songs than her grandfather could.'

b. Marie kan synge flere sanger enn bestefaren hennes kunne $(*$ det).

Marie can sing more songs than grandfather.the her could it

'Marie can sing more songs than her grandfather could.'

That $\overline{\mathrm{A}}$-extraction is not under an absolute ban in clausal comparatives is shown by the fact that the variants in (51) without det, involving apparent simple VP-ellipsis after the modal, are fine. ${ }^{16}$

In contrast to Norwegian, the facts from German come as a surprise: while this language disallows questioning and relativization out of an it-associated pro-predicate, clausal comparatives are licit. ${ }^{17}$ If anything, German speakers show a preference for $e s$ with comparative deletion. ${ }^{18}$

Marie kann mehr Lieder singen als ihr Grossvater (es) konnte.

Marie can more songs sing than her grandfather it could

'Marie can sing more songs than her grandfather could.'

The question, then, is what allows this apparently exceptional extraction just in the comparative cases? Recall that the standard analysis of clausal comparatives involves an unbounded dependency formed between the comparative operator (here represented as n-viele Lieder ' $n$-many songs') and a position inside the clause. We suppose that the predicate es in German is similar to the det of Norwegian in taking a verbal projection as its complement. Putting these two analytical elements together yields the phrase marker for the comparative clause as follows:

a. Marie kann mehr Lieder singen als ihr Grossvater (es) konnte. Marie can more songs sing than her grandfather it could

\footnotetext{
${ }^{16}$ In fact, with comparative deletion, the participial form of gjøre can surface without det:

(i) Marie har sunget flere sanger enn bestefaren hennes har gjort (*det).

Marie has sung more songs than grandfather.the her has done it

We leave the analysis of this use of gjøre aside here, noting only its apparent similarity to the British English do analyzed in Baltin (2012).

${ }^{17}$ Yiddish, according to Jerry Sadock, whom we thank for his judgment of this example, appears to pattern with German in this regard:

(i) Marie kan zingen mer lider az ir zeyde kon (es). Marie can sing more songs than her grandfather could it 'Marie can sing more songs than her grandfather could.'

Dutch, on the other hand, seems to disallow the predicate anaphor het in such comparatives, requiring the bare modal.

${ }^{18}$ This preference is often cited as an absolute requirement; but see Ström Herold (2009):119ff. for counterexamples and discussion.
} 
b.

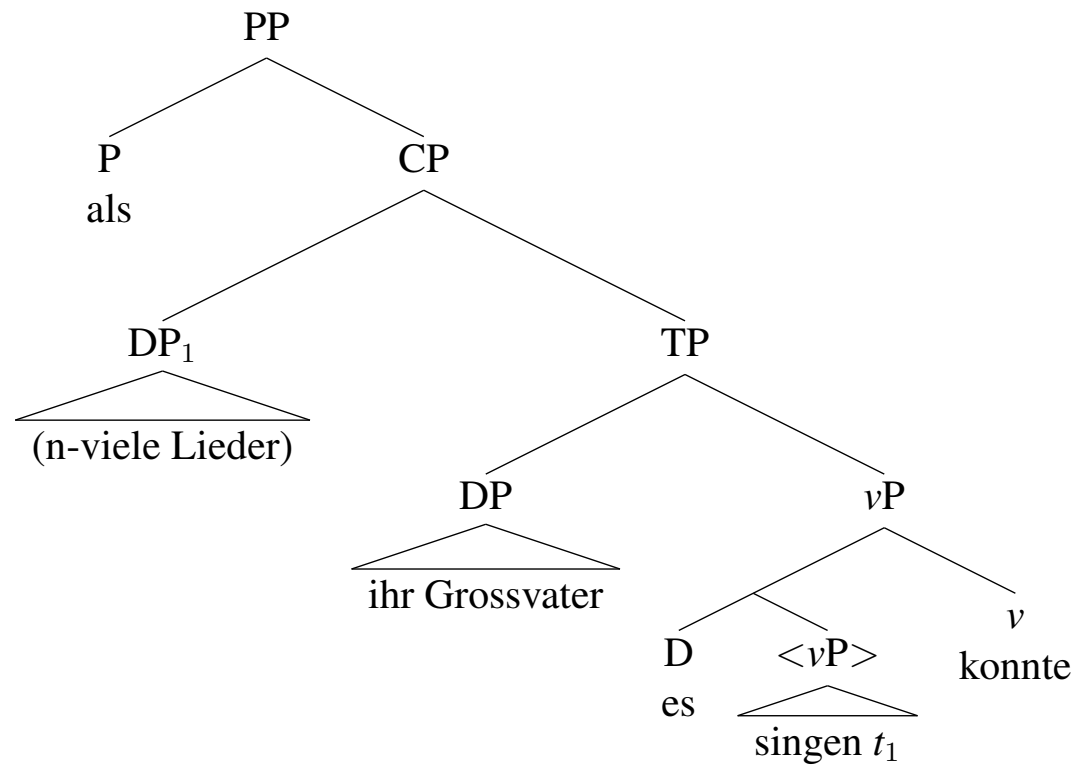

One might suppose that, in contrast to relativization, there is no actual long-distance dependency formed in the comparative, but this solution would require a reanalysis of forty years of data showing that the dependencies in the two constructions are parallel (passing all the standard diagnostics for $\overline{\mathrm{A}}$-dependencies), and we will not pursue such a revisionary route here.

Instead, as for det $_{s}$ above, we can suppose that es is a special kind of nominal element: it selects for an elided verbal predicate (VP or $v \mathrm{P})$. In explicit feature notation, we have: es: [CAT: $\mathrm{N},[\mathrm{E}]$; SEL: V].

Positing the standard $\overline{\mathrm{A}}$-extraction of a (silent) comparative operator makes the correct prediction that these comparatives - even those involving es-propredicates-will be sensitive to islands as usual (see Lechner 2004 for an investigation of German comparatives and a documentation of the island sensitivities):

a. *Marie kann mehr Lieder singen, als ihr Opa einen Mann kennt, der (es)

Marie can more songs sing than her grandpa a man knows who it konnte.

could

(lit. 'Marie can sing more songs than her grandpa knows a man who could.')

Finally, we end with the observation (see also Lederer 1969) that the Infinitivus Pro Participio (IPP) effect is blocked by the presence of $e s:{ }^{19}$

(55) Marie kann mehr Lieder singen, als ihr Grossvater ...

Marie can more songs sing than her grandfather

a. hat singen können. (IPP)

has sing. INF can.INF

\footnotetext{
${ }^{19}$ This can be compared with the lack of exceptional essere with Modal Complement Ellipsis in Italian; see Beltrama (2012).
} 


\section{b. (es) gekonnt hat. \\ it can.PART has \\ c. (*es) hat können. \\ it has can.INF}

This follows from the structure given if the IPP involves exceptional Agree of the lower V and the modal, and if the D-shell layer blocks such upward Agreement. The pattern can also be accounted for on Wurmbrand's (2012) analysis of the IPP, if the modal must be what she terms a 'lexical modal,' to select the DP.

The last remaining question is the following: Why can this es only co-occur with $\overline{\mathrm{A}}$-movement in comparatives? (Compare the lack of $\overline{\mathrm{A}}$-movement out of Modal Complement Ellipsis sites in Dutch, as investigated in Aelbrecht 2010.)

This exceptionality of the behavior of the comparative operator cannot be attributed to the semantic type of the extractee (somehow being checked or specially compatible with es), given that degree and amount questions are ill-formed, as seen above. One possibility, following the similar logic of Aelbrecht (2010) and Baltin (2012), would be to attribute the difference to the timing of extraction, if (i) comparative operators have to extract early (as can elements that Amove or head-move), (ii) VP-ellipsis occurs before other operators can extract, and (iii) elements inside a VP-ellipsis site are inaccessible to further computations or operations (because they are 'deleted' or otherwise) after ellipsis has occurred. Such an implementation is deeply derivational in nature, of course. An alternative would be to posit an appropriate feature encoding: the es that has an intermediate wh-extraction feature also has an unvalued degree feature that can only be valued by als 'than' (cf. the similar logic in Alrenga et al. 2012): $\mathrm{N}\left[e s: u \operatorname{Deg}[\overline{\mathrm{A}}], u \mathrm{THAN} \mathrm{:}_{--}\right]$.

\section{Conclusions}

We have shown that Norwegian det is ambiguous between 'surface' and 'deep' anaphoric uses. We have suggested that this ambiguity is connected to the special use of det as a verbal anaphor;

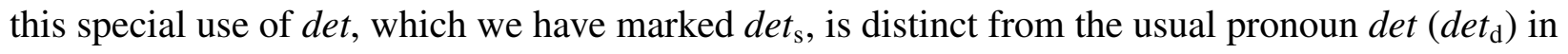
that it fails to undergo Object Shift. Using this as a diagnostic, we showed that the deep anaphoric gjøre det really behaves like any lexical verb plus a pronominal direct object (i.e., gjøre $\operatorname{det}_{\mathrm{d}}$, 'do it'). In the case of the surface anaphoric gjøre det, it is more as if gjфre is a light verb (it shows no aktionsart restrictions) and $\operatorname{det}_{\mathrm{s}}$ is a predicate anaphor of a special kind: it selects for an elided verbal projection. Its anaphoric properties are thus indirect, as a result of the more general requirement that elided material have a certain kind of antecedent.

We documented a novel property of the surface anaphor $\operatorname{det}_{\mathrm{s}}$ : it allows A-movement (and concomitant reconstruction) out of its silent complement but creates a strong island for $\overline{\mathrm{A}}$-movement. This is somewhat surprising since restrictions on A-movement tend to be stricter than those of $\overline{\mathrm{A}}$ movement, and it is difficult to think of other cases where $\mathrm{A}-$, but not $\overline{\mathrm{A}}$-movement is allowed. This restriction was shown to follow if det creates an absolute barrier to $\overline{\mathrm{A}}$-movement (as it seems to when it has an overt clausal associate), but allows QR to target the edge of its elided complement.

Finally, we showed that despite many similarities to the Norwegian det, the propredicate es in German differ in allowing comparative operators to extract from its elided complement. This puzzling behavior is consistent with an extension of our Norwegian analysis to the German case, 
but requires that the German anaphor be featurally specified to only occur in the local domain of a marker of the standard of comparison. This unusual confluence of features is able to accommodate the narrow exception to the ban on $\overline{\mathrm{A}}$-movement that is otherwise observed in German as in Norwegian.

\section{Acknowledgements}

We are grateful to the audience at the Comparative Germanic Syntax Workshop at Yale for comments and reactions, as well as to Anne Dagnac and two reviewers for detailed and helpful written suggestions. We would also like to thank the Norwegian speakers who participated in our survey at Lysebu, Norway in August 2012.

\section{References}

Aelbrecht, Lobke. 2010. The syntactic licensing of ellipsis. Amsterdam: John Benjamins.

Alrenga, Peter, Chris Kennedy, and Jason Merchant. 2012. A new standard of comparison. In Proceedings of WCCFL 30, ed. James McCloskey. UC, Santa Cruz. West Coast Conference on Formal Linguistics. West Coast Conference on Formal Linguistics.

Anderssen, Merete, and Kristine Bentzen. 2012. Scandinavian Object Shift as IP-internal topicalization. Nordlyd 39 (1): 1-23. available at http://septentrio.uit.no/index.php/nordlyd/issue/view/205.

Andréasson, Maia. 2009. Pronominal object shift - not just a matter of shifting or not. Working Papers in Scandinavian Syntax 84: 1-20.

Andréasson, Maia. 2010. Object shift or object placement in general. In Proceedings of the LFG10 conference, eds. Miriam Butt and Tracy Halloway King, 26-42.

Andréasson, Maia. 2013. Object shift in Scandinavian languages - the impact of contrasted elements. Nordic Journal of Linguistics 36 (2): 187-217.

Baltin, Mark. 2012. Deletion vs. pro-forms: an overly simple dichotomy? Natural Language and Linguistic Theory 30 (2): 381-423.

Beltrama, Andrea. 2012. Modal complement ellipsis in Italian. Ms., University of Chicago.

Bentzen, Kristine. 2012. Successive cyclic movement and extraction from embedded clauses: Puzzles from Norwegian. Paper presented at the Mini workshop in connection with Éva Dékány's defense, CASTL, University of Troms $\varnothing$, Norway.

Bentzen, Kristine, and Merete Anderssen. 2012. Norwegian Object Shift: The role of reference and topichood. Paper presented at the Workshop on Scandinavian Object Shift, Gothenburg, Sweden.

Bentzen, Kristine, Merete Anderssen, and Christian Waldmann. 2013. Object Shift in spoken Mainland Scandinavian: A corpus study of Danish, Norwegian, and Swedish. Nordic Journal of Linguistics 36 (2): 115-151.

Berman, Judith. 1998. On the syntax of correlative es and finite clauses in German: an LFG analysis. In Proceedings of ESSLI, 1-25. Universität des Saarlandes.

Borthen, Kaia. 2003. Norwegian bare singulars. PhD diss, NTNU, Trondheim. 
Bresnan, Joan. 1971. A note on the notion 'identity of sense anaphora'. Linguistic Inquiry 2 (4): 589-597.

Cable, Seth. 2010. The grammar of Q: Q-particles, wh-movement and pied-piping. Oxford: Oxford University Press.

Chomsky, Noam. 1977. On wh-movement. In Formal syntax, eds. P. Culicover, T. Wasow, and A. Akmajian. New York, New York: Academic Press.

Collins, Chris. 2005. A smuggling approach to the passive in English. Syntax 8 (2): 81-120.

Déchaine, Rose-Marie, and Martina Wiltschko. 2002. Decomposing pronouns. Linguistic Inquiry 33 (3): 409-442.

Elbourne, Paul. 2008. Ellipsis sites as definite descriptions. Linguistic Inquiry 39 (2): 191-220.

Elbourne, Paul. 2010. The existence entailments of definite descriptions. Linguistics and Philosophy 33 (1): 1-10.

Fox, Danny. 2000. Economy and semantic interpretation. Cambridge, Ma.: MIT Press.

Grinder, John, and Paul M. Postal. 1971. Missing antecedents. Linguistic Inquiry 2: 269-312.

Hankamer, Jorge, and Ivan Sag. 1976. Deep and surface anaphora. Linguistic Inquiry 7 (3): 391426.

Hardt, Daniel, Line Mikkelsen, and Bjarne Ørsnes. 2011. Sameness, ellipsis and anaphora. In Pre-proceedings of the 18th Amsterdam colloquium, 322-331. Amsterdam: Institute for Logic, Language and Computation.

Holmberg, Anders. 1999. Remarks on Holmberg's Generalization. Studia Linguistica 53 (1): 139.

Houser, Michael, Line Mikkelsen, and Maziar Toosarvandani. 2011. A defective auxiliary in Danish. Journal of Germanic Linguistics 23 (3): 245-298.

Houser, Michael J., Line Mikkelsen, and Maziar Toosarvandani. 2007. Verb phrase pronominalization in Danish: Deep or surface anaphora? In Proceedings of WECOL 34, eds. Eric Brainbridge and Brian Agbayani, 183-195.

Johnson, Kyle. 2012. The Leiden lectures on anaphora and ellipsis. A series of extensive prose handouts from lectures delivered at the University of Leiden.

Johnson, Kyle, and Satoshi Tomioka. 1998. Lowering and mid-size clauses. In Proceedings of the 1997 Tübingen workshop on reconstruction, eds. Graham Katz, Shin-Sook Kim, and Winhart Haike, 185-206. Tübingen, Germany: Sprachteoretische Grundlagen für die Computer Linguistik.

Lechner, Winfried. 2004. Ellipsis in comparatives. Berlin: Mouton de Gruyter.

Lederer, Herbert. 1969. Reference grammar of German. New York: Prentice Hall.

Lødrup, Helge. 1994. 'Surface proforms' in Norwegian and the definiteness effect. In Proceedings of the North East Linguistic Society 24, 303-315. Amherst, Ma.: GLSA.

Lødrup, Helge. 2012. Some Norwegian 'type' anaphors are surface anaphora. Journal of Germanic Linguistics 24 (1): 23-52.

López, Luis, and Susanne Winkler. 2000. Focus and topic in VP-anaphora constructions. Linguistics 38 (4): 623-664.

Merchant, Jason. 2004. Fragments and ellipsis. Linguistics and Philosophy 27 (6): 661-738. 
Merchant, Jason. 2013. Diagnosing ellipsis. In Diagnosing syntax, eds. Lisa Lai-Shen Cheng and Norbert Corver, 537-542. Oxford: Oxford University Press.

Mikkelsen, Line. 2011. On prosody and focus in Object Shift. Syntax 14 (3): 230-264.

Miller, Philip, and Geoffrey K. Pullum. 2013. Exophoric VP ellipsis. In The core and the periphery: Data-driven perspectives on syntax inspired by Ivan A. Sag, eds. Philip Hofmeister and Elisabeth Norcliffe, 5-32. Stanford, Calif.: CSLI Publications.

Ørsnes, Bjarne. 2011. Non-finite do-support in Danish. In Empirical issues in syntax and semantics 8, eds. Olivier Bonami and Patricia Cabredo Hofherr, 1-25.

Ørsnes, Bjarne. 2013. VP-anaphors and Object Shift: What do VP-anaphors reveal about the licensing conditions for Object Shift in Danish? Nordic Journal of Linguistics 36 (2): 245-274.

Platzack, Christer. 2012. Cross Germanic variation in the realm of support verbs. In Comparative Germanic syntax: The state of the art, eds. Peter Ackema, Rhona Alcorn, Caroline Heycock, Dany Jaspers, Jeroen Van Craenenbroeck, and Guido Vanden Wyngaerd. Linguistik aktuell/linguistics today, 279-310. Amsterdam: John Benjamins.

Sag, Ivan A. 1976. Deletion and logical form. PhD diss, MIT, Cambridge, Ma..

Sag, Ivan A., and Jorge Hankamer. 1984. Toward a theory of anaphoric processing. Linguistics and Philosophy 7 (3): 325-345.

Sportiche, Dominique. 1995. French predicate clitics and clause structure. In Small clauses: Syntax and semantics vol. 28, eds. Anna Cardinaletti and Maria Teresa Guasti, 287-324. New York: Academic Press.

Ström Herold, Jenny. 2009. Proformen und Ellipsen. Zur Syntax und Diskurspragmatik prädikativer Anaphern im Deutschen und im Schwedischen. Lund: Media-Tryck.

van Craenenbroeck, Jeroen. 2010. The syntax of ellipsis: Evidence from Dutch dialects. Oxford: Oxford University Press.

van Craenenbroeck, Jeroen. 2012. Ellipsis and accommodation. ms. Hoegeschool-Universiteit Brussel.

Winkler, Susanne. 2005. Ellipsis and focus in generative grammar. Berlin: Walter de Gruyter.

Winkler, Susanne. 2013. Syntactic diagnostics for island sensitivity of contrastive focus in ellipsis. In Diagnosing syntax, eds. Lisa L. S. Cheng and Norbert Corver, 463-484. Oxford: Oxford University Press.

Wurmbrand, Susanne. 2012. Parasitic participles in Germanic: Evidence for the theory of verb clusters. Taal en tongval 64 (1): 129-156. 